\title{
Microstructural Characterization and Corrosion-Resistance Behavior of Dual-Phase Steels Compared to Conventional Rebar
}

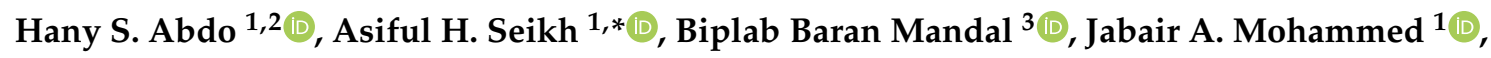 \\ Sameh A. Ragab ${ }^{1}$ and Mohamed S. Abdo ${ }^{4}$ \\ 1 Centre of Excellence for Research in Engineering Materials, King Saud University, Riyadh 11421, \\ Saudi Arabia; habdo@ksu.edu.sa (H.S.A.); jmohammed@ksu.edu.sa (J.A.M.); sragab@ksu.edu.sa (S.A.R.) \\ 2 Mechanical Design and Materials Department, Faculty of Energy Engineering, Aswan University, \\ Aswan 81521, Egypt \\ 3 Department of Mechanical Engineering, Jadavpur University, Kolkata 700032, India; \\ biplab.mandal81@gmail.com \\ 4 Biomedical Engineering Department, Faculty of Engineering, Minia University, Minia 61519, Egypt; \\ bioengmsa@yahoo.com \\ * Correspondence: aseikh@ksu.edu.sa; Tel.: +966-559204166
}

Received: 22 October 2020; Accepted: 21 November 2020; Published: 23 November 2020

\begin{abstract}
Dual-phase (DP) steels consist of a ferritic matrix dispersed with some percentage of martensite, which gives the material a good combination of strength and ductility, along with the capacity to absorb energy and enhanced corrosion protection properties. The purpose of this work was to study the microstructural and corrosion behavior (mainly pitting and galvanic corrosion) of DP steel compared with that of conventional rebar. To obtain DP steel, low-carbon steels were heat-treated at $950{ }^{\circ} \mathrm{C}$ for $1 \mathrm{~h}$ and then intercritically annealed at $771{ }^{\circ} \mathrm{C}$ for $75 \mathrm{~min}$, followed by quenching in ice-brine water. The corrosion rates of DP steel and standard rebar were then measured in different pore solutions. Macro- and microhardness tests were performed for both steels. It was found that DP steels exhibited a superior corrosion resistance and strength compared to standard rebar. The reported results show that DP steels are a good candidate for concrete reinforcement, especially in aggressive and corrosive environments.
\end{abstract}

Keywords: dual-phase steel; rebar; annealing; corrosion resistance; microstructure

\section{Introduction}

Steel is mankind's most eminent structural material and has led to technological breakthroughs in different fields, including safety, energy, automobiles, and construction. Due to their durability and versatility, reinforced steel bars (rebars) are used extensively in construction.

From a corrosion protection point of view, the main challenge faced in the conventional rebar-based reinforcement of concrete is to minimize the rate of corrosion that occurs due to passive-layer breakdown, which typically occurs because of the reaction of chloride ions over the steel surface under an appropriately alkaline environment [1-3]. Various studies have been performed to investigate the relationship between the corrosion rate and chloride concentration $(\mathrm{Cl} \%)$ in the environment surrounding steel bars, especially that under alkaline conditions [2-7]. The main objective is to optimize the different conditions in order to generate a $\mathrm{Cl} \%$ that initiates pitting. It has been reported by different researchers that the $\mathrm{Cl} \%$ varies according to numerous variables and parameters. For instance, $\mathrm{Li}$ and Sagüés [3] showed that the critical $\mathrm{Cl} \%$ was somewhere between 0.01 and $0.04 \mathrm{M}$ in saturated calcium hydroxide, while that concentration reached $0.4-0.6 \mathrm{M}$ in a simulated concrete pore solution 
(SCPS-PH-13.5). According to Bertolini et al. [4], there is a relationship between the critical $\mathrm{Cl} \%$ for carbon steel and the $\mathrm{pH}$ value of the solution. As typical values, the $\mathrm{Cl} \%$ increased from $0.17 \mathrm{M}$ at $\mathrm{pH}$ 12.5 to more than $0.27 \mathrm{M}$ at $\mathrm{pH} 13.8$ in a sodium hydroxide solution.

It was reported by Hausmann [5] that, after immersing steel in sodium hydroxide solution ( $\mathrm{pH}$ 13.2) and then adding $0.25 \mathrm{M}$ sodium chloride, the whole mixture remained in the passive state. However, it was concluded by Gouda [6] that a sodium chloride concentration up to $0.007 \mathrm{M}$ was not sufficient to change the steel passivity in a saturated calcium hydroxide solution. In addition, he found that the maximum concentration of sodium chloride that could be added to a sodium hydroxide solution ( $\mathrm{pH} 13.9$ ) to change the steel passivity was $\sim 0.12 \mathrm{M}$.

Recently, due to its combination of strength and formability, extensive progress has been made in the improvement of advanced dual-phase (DP) steel. Whereas most kind of steels, such as ferrite steel, have a single microstructural phase, DP steel typically has a multiphase-combination of bainite, ferrite, and martensite phases. The high ductility and strength characteristics of such alloys are due to the unique microstructure of DP steel. Accordingly, there has been significant scientific and engineering interest in DP steel in the last decade [7,8].

The characteristic feature of DP steel is a microstructure consisting of a matrix of fine ferrite containing small spots of a second harder phase. Although a small percentage of retained austenite or bainite might be present, this second phase mainly consists of martensite. The volume fraction of martensite typically ranges between $10 \%$ and $20 \%$ (ranges from $5 \%$ to $30 \%$ are also found in the literature). The hard martensite islands provide substantial strengthening, while formability is provided by the ductile ferrite matrix [9-16]. DP steel in reinforced concrete exhibits a very good corrosion resistance.

Many variables affect the ductility of an element (especially the bending moment) when it is subjected to different loads, such as the element material, cross-section geometry, and mechanical properties. For reinforced concrete, these variables and parameters can be represented by the mechanical properties of the concrete, the reinforcement ductility, the bonding between the reinforcement and concrete, the cross-section geometry, the structural details, the transverse shear and longitudinal force, and the element slenderness. The intercritical quenching process is a very effective operation used to improve the ferrite-martensite structure by enhancing the density of the mobile dislocations and increasing the residual stresses. DP steel acquires its superior mechanical properties due to the formation of two phases (i.e., a ferrite/martensite interface) [15,17-24].

The objective of the present work was to study and compare the microstructural features and corrosion behaviors of standard rebar and DP steels.

\section{Materials and Methods}

\subsection{Heat Treatment}

The as-received material with the typical chemical composition shown in Table 1 was heat-treated using a tube furnace. To obtain a DP structure, low-carbon steels were heat-treated at $950{ }^{\circ} \mathrm{C}$ for a period of $1 \mathrm{~h}$ and then intercritically annealed at $771^{\circ} \mathrm{C}$ for $75 \mathrm{~min}$, followed by quenching in ice-brine water. The average temperature of the ice-brine water was $-8^{\circ} \mathrm{C}$, at which the conversion of phases starts and new microstructures are easily formed and homogeneous. A schematic of the heat-treatment process is shown in Figure 1. A differential thermal analysis of the as-received material was performed with heating from 55 to $975{ }^{\circ} \mathrm{C}$ at $15{ }^{\circ} \mathrm{C} / \mathrm{min}$ using a DT-40 thermal analyzer (Shimadzu, Japan) to determine intercritical ranges such as the $\mathrm{AC} 1$ and $\mathrm{AC} 3$ temperatures. $\alpha-\mathrm{Al}_{2} \mathrm{O}_{3}$ was used as the reference material. 
Table 1. Chemical composition of the studied steels (wt \%).

\begin{tabular}{ccccccccc}
\hline & $\mathbf{C}$ & $\mathbf{M n}$ & $\mathbf{S i}$ & $\mathbf{S}$ & $\mathbf{P}$ & $\mathbf{V}$ & $\mathbf{M o}$ & $\mathbf{N b}$ \\
\hline DP Steel & 0.21 & 0.80 & 0.172 & 0.023 & 0.017 & $<0.01$ & $<0.01$ & $<0.01$ \\
standard rebar & 0.25 & 0.82 & 0.170 & 0.035 & 0.015 & $<0.01$ & $<0.01$ & $<0.01$ \\
\hline
\end{tabular}

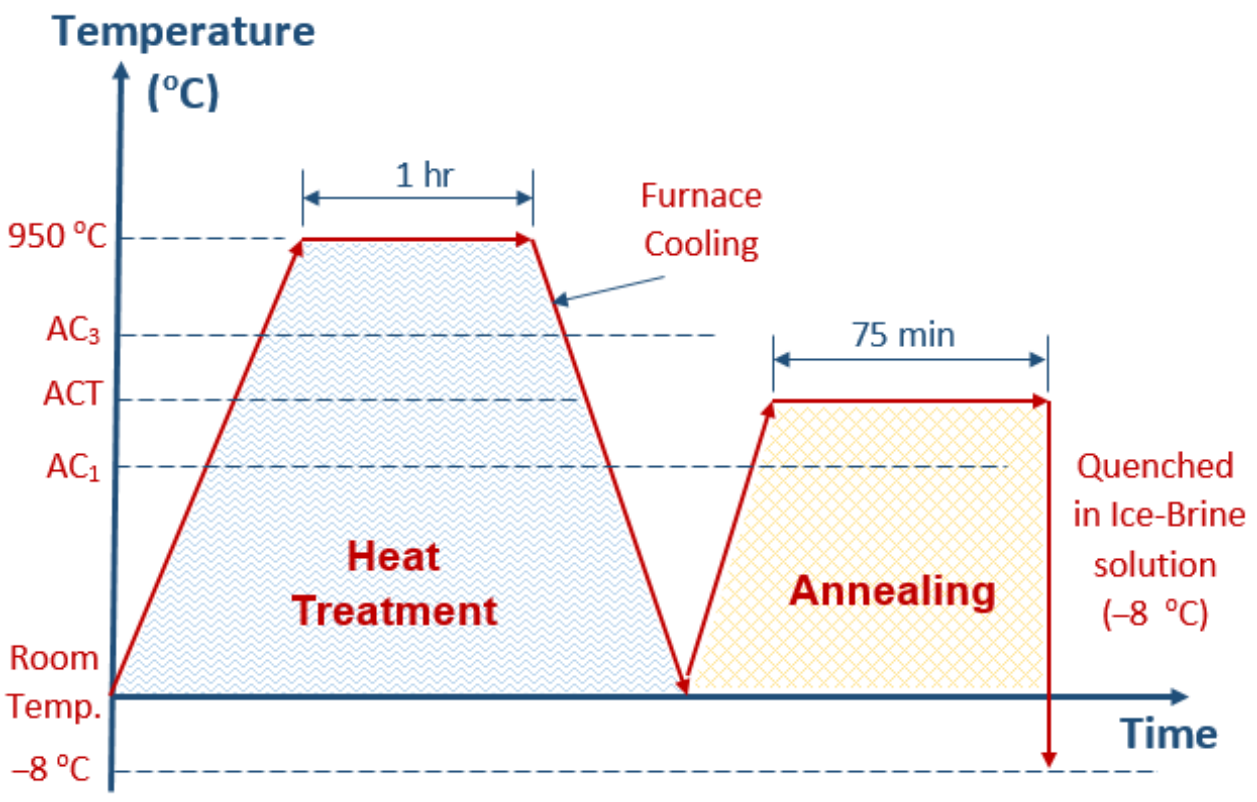

Figure 1. Schematic of the total heat-treatment process.

\subsection{Metallography}

Small specimens (10-mm cubes) were cut from the as-received sample and heat-treated samples for optical metallography. For this purpose, the specimens were cut along the perpendicular direction of the longitudinal axis using a StruersSecoTom10 machine. These specimens were polished with successively fine SiC abrasive paper (320, 400, 600, 800, 1000, 1200, 1500, 2000, and 2500). Then, the samples were cloth-polished in a SPECTRUM SYSTEM ${ }^{\mathrm{TM}} 1000$ to make the samples scratch-free. Ferrous alumina was used as a lubricant during cloth polishing.

The specimens were then thoroughly cleaned with water followed by ethanol (96\% purity, from Sigma-Aldrich), and finally dried. The scratch-free polished specimens were etched with $2 \%$ nital solution and observed under a Leica DM 2500M optical microscope. Ten different fields were observed, and the digital images of the microstructures were used for the quantitative characterization of the steel microstructures. An image analysis was performed with the Leica Application Suite, Version V4.4.

\subsection{Hardness Measurement}

The hardnesses of the as-received rebar and intercritically quenched samples were measured using a Vicker's hardness tester at an applied load of $100 \mathrm{~g}$ for $10 \mathrm{~s}$ according to the ASTM E92 standard. An average of five different fields was considered in this study.

\subsection{Volume Fraction Calculation}

The volume fractions of intercritically quenched specimens were determined using the Leica automatic image analyzer. At least 10 fields on the surfaces of the polished and etched specimens were studied at a suitable magnification in order to acquire a statistically reliable result. The data were averaged so as to obtain the volume percentage of martensite. 


\subsection{Corrosion Testing}

Small specimens were taken from the midregions of the heat-treated samples, and the corrosion behavior was studied by potentiodynamic polarization and electrochemical impedance techniques in different pore solution concentrations using a potentiostat. Small specimens were cut from both materials and mounted using an epoxy resin before polishing one surface to prepare it for microstructural imaging. Experiments were performed at ambient temperature $\left(27^{\circ} \mathrm{C}\right)$ using a conventional three-electrode cell with a graphite rode as the counter electrode and a saturated calomel electrode as the reference electrode. A working electrode with a $1-\mathrm{cm}^{2}$ area was sealed with epoxy resin. Prior to the tests, the samples were polished using 2500 grit-size SiC paper, rinsed in deionized water, and immersed in the solution for $30 \mathrm{~min}$ in order to stabilize the open circuit potential value. Potentiodynamic polarization curves were recorded at a constant scan rate of $10 \mathrm{mV} / \mathrm{s}$ at the interval of -1500 to $+2500 \mathrm{mV}_{\mathrm{SCE}}$. An electrochemical impedance spectroscopy analysis was performed over the frequency range of $100 \mathrm{kHz}$ to $0.01 \mathrm{~Hz}$.

\section{Results}

\subsection{Microstructure}

The microstructure of the as-received rebar showed dark and white regions, as shown in Figure 2a. The white regions represent the ferrite phase, and the dark regions represent pearlite. The grains are oriented in the longitudinal direction, and bands are observed in the microstructure.
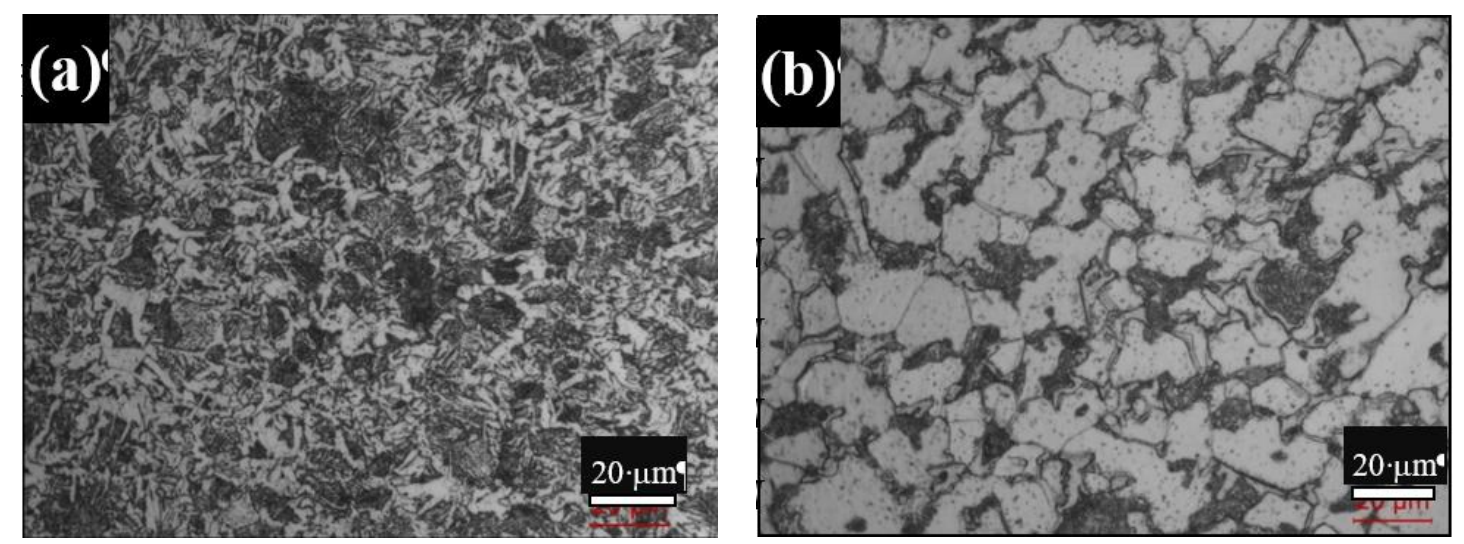

Figure 2. Microstructural images of (a) standard rebar and (b) DP steel after heat treatment.

The microstructure of the DP steel as shown in Figure $2 b$ consists of hard martensite and soft ferrite. The relative amounts of ferrite and martensite were determined using Leica LS image analyzer software to measure the area fractions. The thickness of the sample was $0.90 \mathrm{~mm}$ after polishing, so there was a negligible variation of phases along the thickness of the sample. Therefore, the area fraction was considered as the volume fraction. Accordingly, the volume fraction of martensite in the DP steel was found to be $21.2 \%$.

\subsection{Hardness}

The average hardness value (Table 2) obtained from five indentations at different areas for each sample was considered to be the approximate microhardness value for that particular region.

Table 2. Average hardness values.

\begin{tabular}{cc}
\hline Sample & Hardness (VHN) \\
\hline Standard rebar & 257 \\
DP steel & 310 \\
\hline
\end{tabular}




\subsection{Potentiodynamic Polarization}

\subsection{1. $\mathrm{NaOH}(0.9 \mathrm{M}, \mathrm{pH}=13.9)+0.2 \% \mathrm{Cl}^{-}$Solutions}

It is clear from Figure 3 that the chloride concentration plays an important role in determining the passive zone. However, there is an inverse relationship between the chloride concentration and pitting potential. Therefore, increasing the chloride concentration leads to an increase in the passive current density and a decrease in the pitting potential, which in turn leads to corrosion activity and the formation of pitting spots on the metallic surface. The behavior of both DP and standard rebar in the above solution are shown in Figure 4. Which the anodic polarization curves for standard rebar steel obtained by immersing rebar segments in different concentrations of chloride ions added to 0.9 M sodium hydroxide solution. Initially, rebar segments were used in the passive form in order to determine the free corrosion potential. Increasing the chloride ion concentration substantially affects the steel anodic behavior. The corrosion rate of DP is lower than that of rebar steel in the same solution, as confirmed by the scanning electron microscopy (SEM) images in Figure 5a,b.

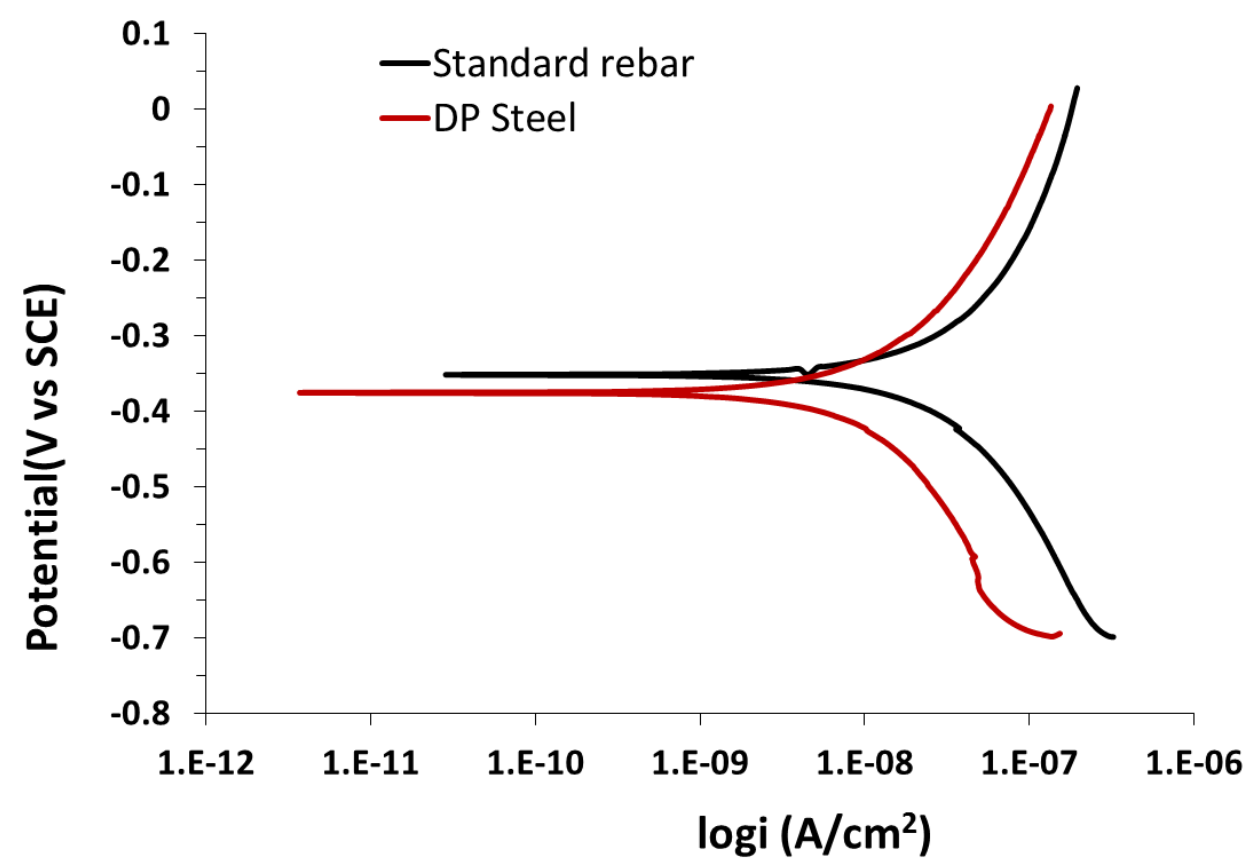

Figure 3. Potentiodynamic polarization results for standard rebar and DP steel in $0.9 \mathrm{M} \mathrm{NaOH}$ $(\mathrm{pH}=13.9)+0.2 \% \mathrm{Cl}^{-}$solution.

The SEM images clearly show that rebar (Figure 5a) has a higher pitting density than that of DP steel (Figure $5 b)$ in $0.9 \mathrm{M} \mathrm{NaOH}(\mathrm{pH}=13.9)+0.2 \% \mathrm{Cl}^{-}$solution. The parameters obtained from Figures 3 and 4 are listed in Table 3 . Here, $\mathrm{E}_{\mathrm{Corr}}$ is the corrosion potential and $\mathrm{j}_{\text {Corr }}$ is the corrosion current density.

Table 3. EIS results for DP steel and standard rebar in $0.9 \mathrm{M} \mathrm{NaOH}(\mathrm{pH}=13.9)+0.2 \% \mathrm{Cl}^{-}$solution.

\begin{tabular}{ccccc}
\hline Sample & $\begin{array}{c}\text { Icorr } \\
\left(\mu \mathrm{A} / \mathbf{c m}^{\mathbf{2}}\right)\end{array}$ & $\begin{array}{c}\text { Ecorr } \\
\mathbf{( V )}\end{array}$ & $\begin{array}{c}\mathbf{R p} \\
\left(\mathbf{\Omega} \cdot \mathbf{c m}^{\mathbf{2}}\right)\end{array}$ & $\boldsymbol{\alpha}$ \\
\hline Standard rebar & 14 & -0.36 & 175 & -0.80 \\
DP steel & 9 & -0.38 & 300 & -0.93 \\
\hline
\end{tabular}




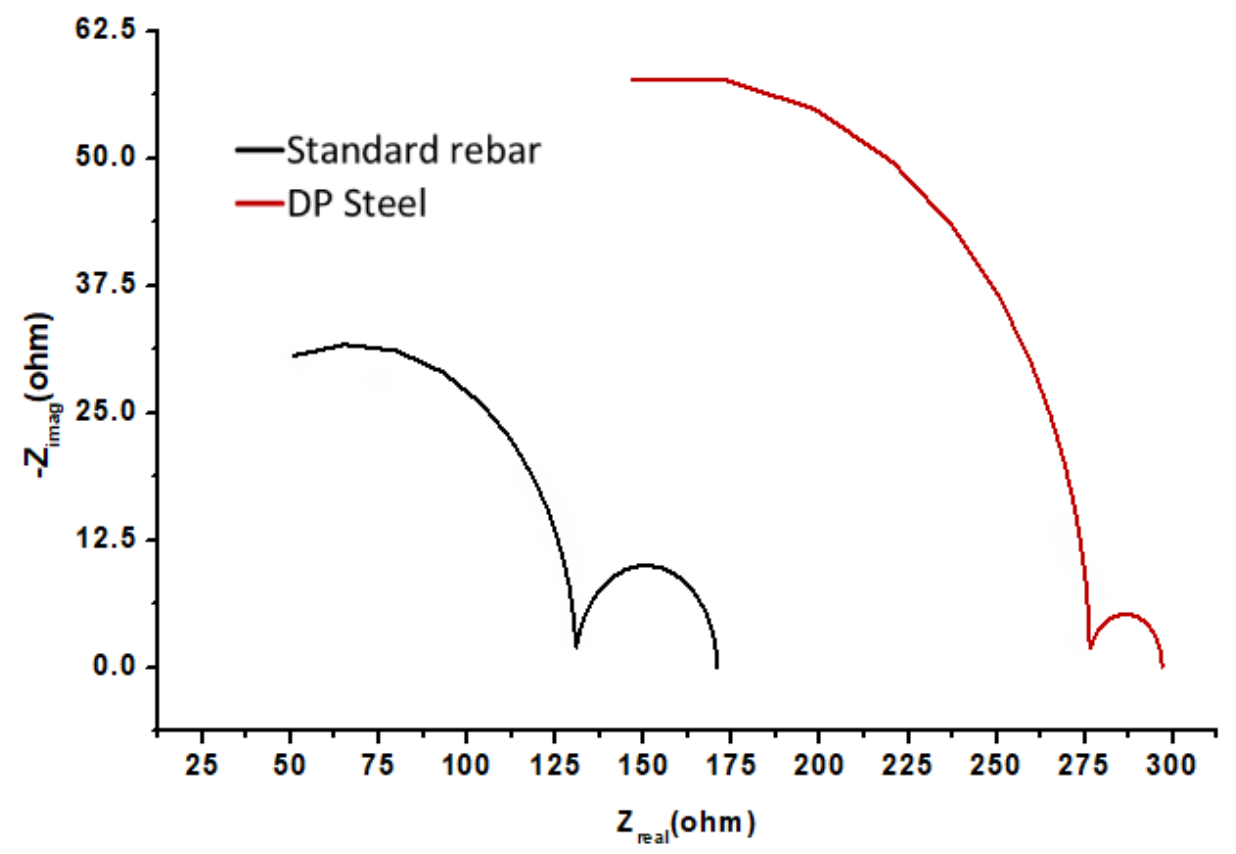

Figure 4. EIS results (Nyquist plots) for DP steel and standard rebar in $0.9 \mathrm{M} \mathrm{NaOH}(\mathrm{pH}=13.9)+0.2 \%$ $\mathrm{Cl}^{-}$solution.
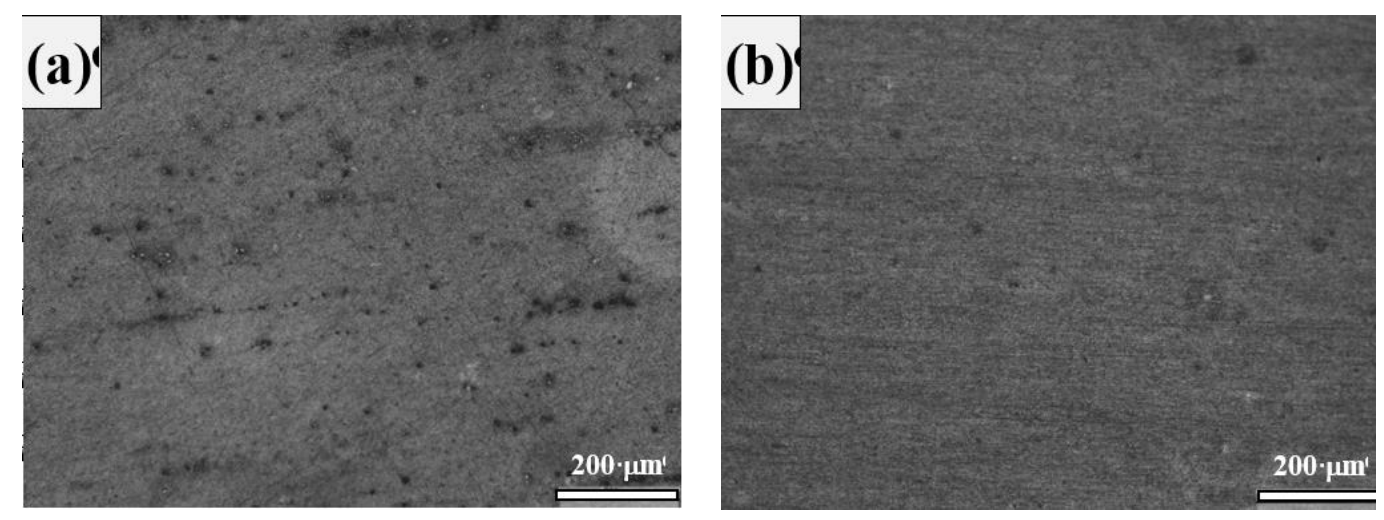

Figure 5. SEM images obtained after immersion in $0.9 \mathrm{M} \mathrm{NaOH}(\mathrm{pH}=13.9)+0.2 \% \mathrm{Cl}^{-}$solutions.

(a) Standard rebar and (b) DP steel.

\subsubsection{Saturated $\mathrm{Ca}(\mathrm{OH})_{2}(\mathrm{pH}=12.5)+0.2 \% \mathrm{Cl}^{-}$Solutions}

The behaviors of standard rebar and DP steel in the above solution are shown in Figures 6 and 7. There is no significant difference on the anodic polarization graphs recorded in saturated calcium hydroxide solution. The only difference is the slightly higher value of the potentials, which is mainly because of the lower $\mathrm{pH}$ value of the calcium hydroxide solution. 


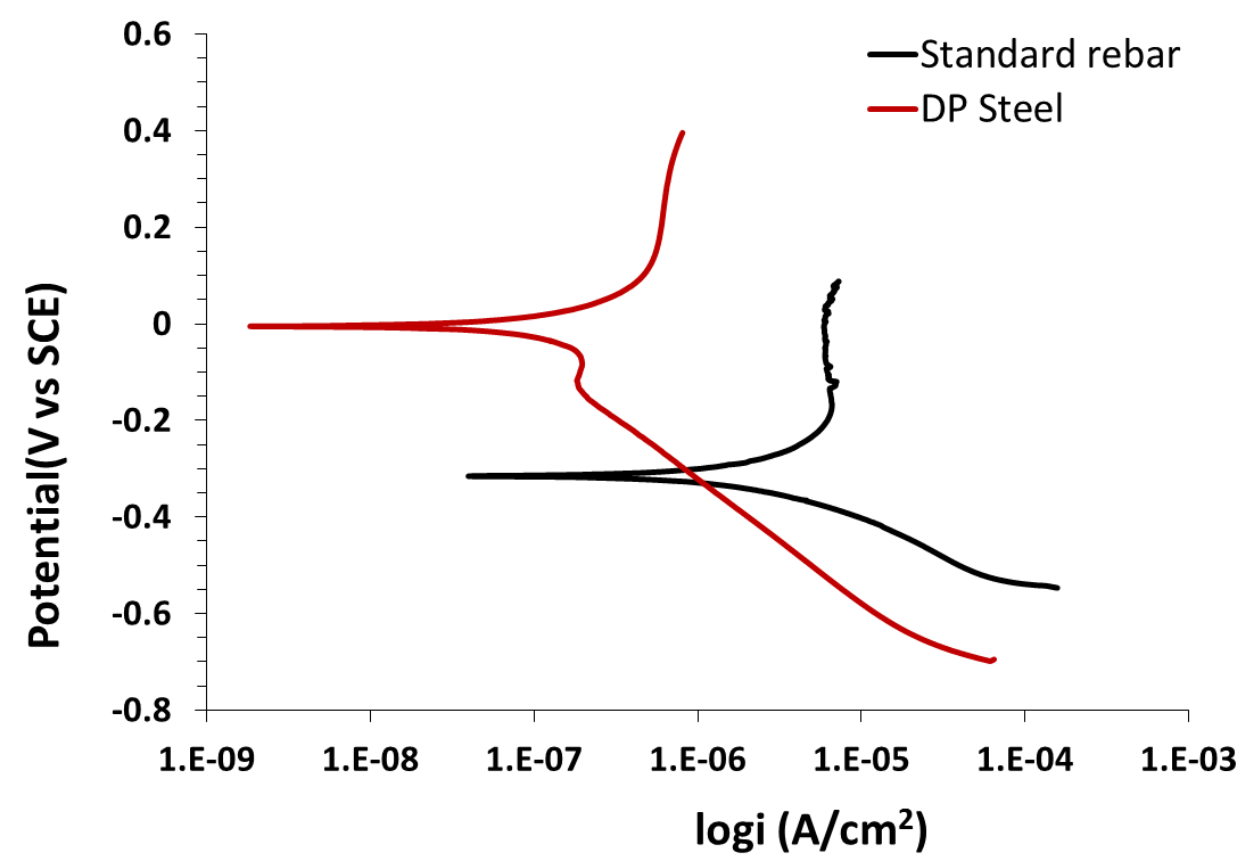

Figure 6. Comparison of the potentiodynamic polarization results for standard rebar and DP steel recorded in saturated $\mathrm{Ca}(\mathrm{OH})_{2}(\mathrm{pH}=12.5)+0.2 \% \mathrm{Cl}^{-}$solution.

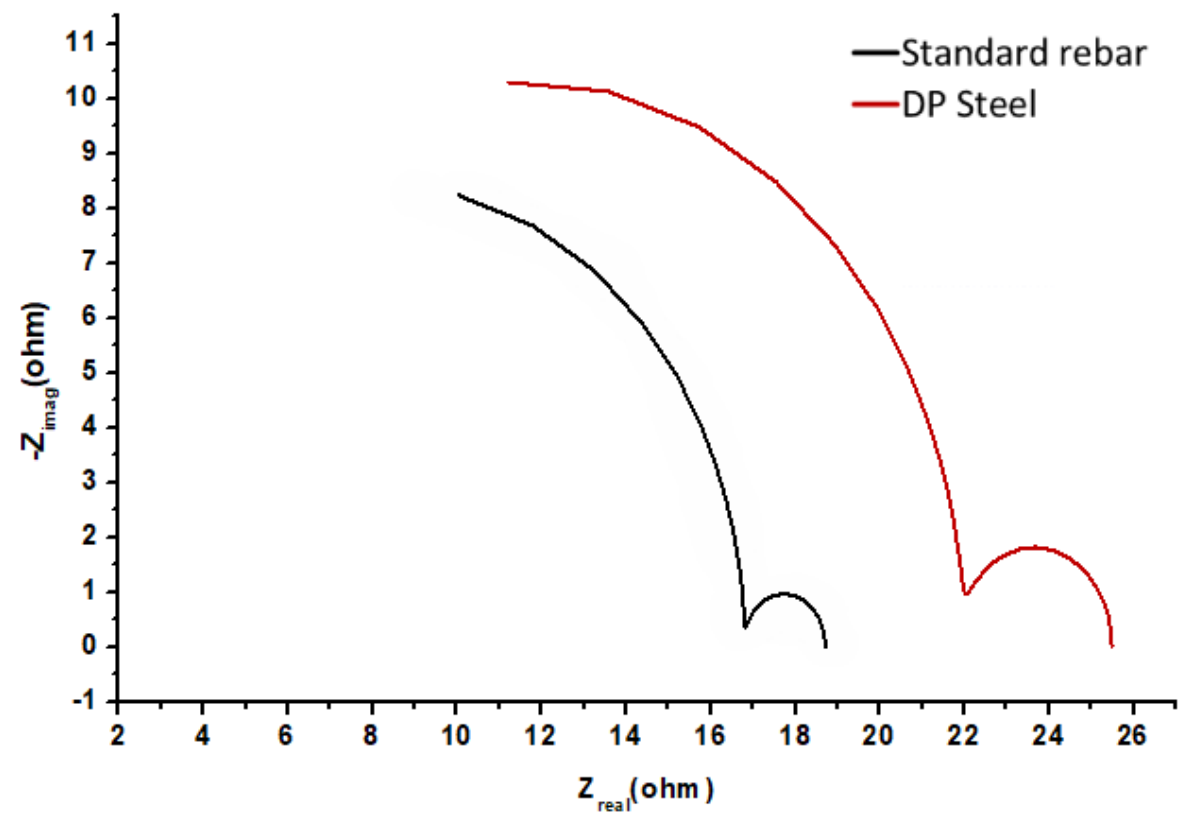

Figure 7. EIS results (Nyquist plots) for standard rebar and DP steel in saturated $\mathrm{Ca}(\mathrm{OH})_{2}(\mathrm{pH}=12.5)$ $+0.2 \% \mathrm{Cl}^{-}$solution.

The SEM images clearly show that standard rebar (Figure 8a) has a higher pitting density than that of DP steel (Figure $8 \mathrm{~b}$ ) in saturated $\mathrm{Ca}(\mathrm{OH})_{2}(\mathrm{pH}=12.5)+0.2 \% \mathrm{Cl}^{-}$solution. This confirms that rebar is more prone to pitting corrosion than DP steel. The parameters obtained from Figures 6 and 7 are listed in Table 4 . Here, $\mathrm{E}_{\mathrm{Corr}}$ is the corrosion potential and $\mathrm{j}_{\mathrm{Corr}}$ is the corrosion current density. 

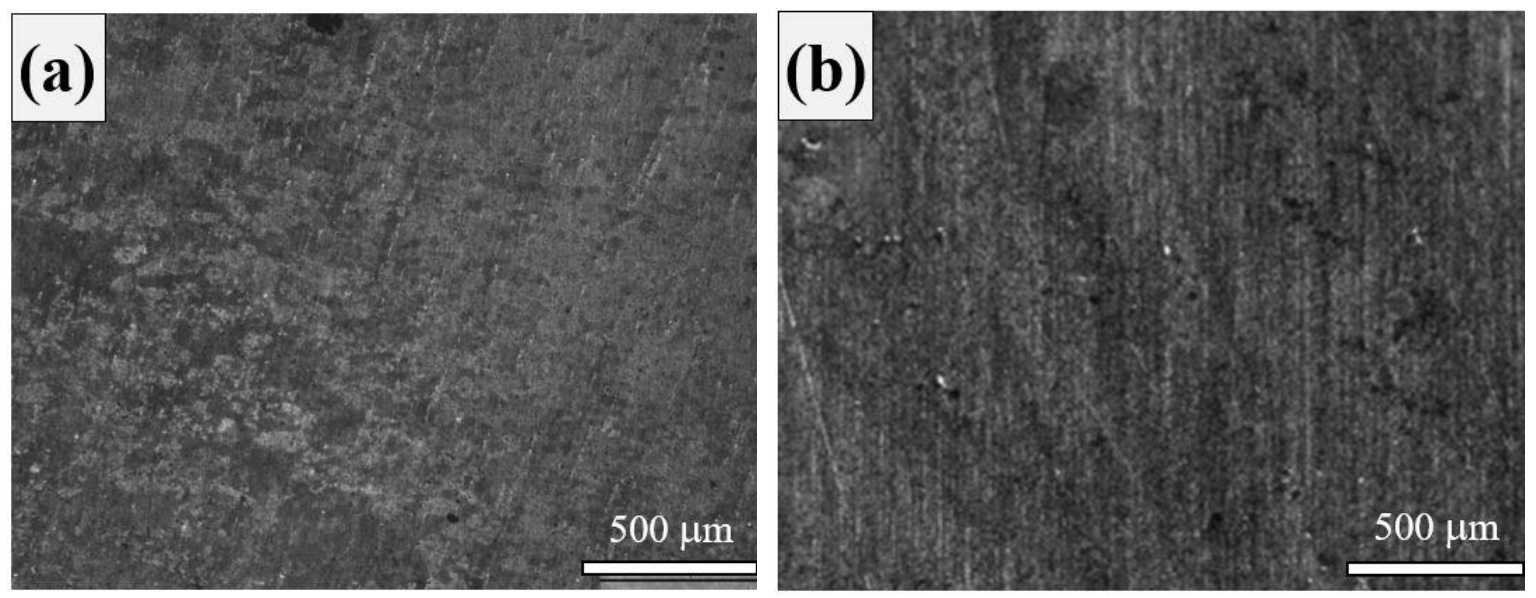

Figure 8. SEM images obtained after immersion in saturated $\mathrm{Ca}(\mathrm{OH})_{2}(\mathrm{pH}=12.5)+0.2 \% \mathrm{Cl}^{-}$solutions. (a) Standard rebar and (b) DP steel.

Table 4. EIS results for DP steel and standard rebar in saturated $\mathrm{Ca}(\mathrm{OH})_{2}(\mathrm{pH}=12.5)+0.2 \% \mathrm{Cl}^{-}$solution.

\begin{tabular}{ccccc}
\hline Sample & $\begin{array}{c}\text { Icorr } \\
\left(\boldsymbol{\mu} \mathbf{A} / \mathbf{c m}^{\mathbf{2}}\right)\end{array}$ & $\begin{array}{c}\text { Ecorr } \\
(\mathbf{V})\end{array}$ & $\begin{array}{c}\mathbf{R p} \\
\left(\mathbf{\Omega} \cdot \mathbf{c m}^{\mathbf{2}}\right)\end{array}$ & $\boldsymbol{\alpha}$ \\
\hline Standard rebar & 156 & 0.10 & 18 & -0.65 \\
DP steel & 45 & -0.30 & 26 & -0.71 \\
\hline
\end{tabular}

\subsection{3. $0.3 \mathrm{M} \mathrm{NaHCO}_{3}+0.1 \mathrm{M} \mathrm{Na}_{2} \mathrm{CO}_{3}(\mathrm{pH}=9.0)$ Solution}

Compared to the polarization trend in most alkaline solutions, the polarization behaviors of standard rebar in a solution consisting of $\mathrm{NaHCO}_{3}$ (sodium bicarbonate) and $\mathrm{Na}_{2} \mathrm{CO}_{3}$ (sodium carbonate) are very similar. In the same manner, the pitting potential follows the same trend, while the corrosion potential and pitting potential are related to the chloride content. A high chloride concentration leads to a low pitting potential. Therefore, corrosion products will form on the exposed metallic surface. The corrosion rate of DP is lower than that of rebar in this solution. The behavior of standard rebar and DP steel in the above solution are shown in Figures 9 and 10.

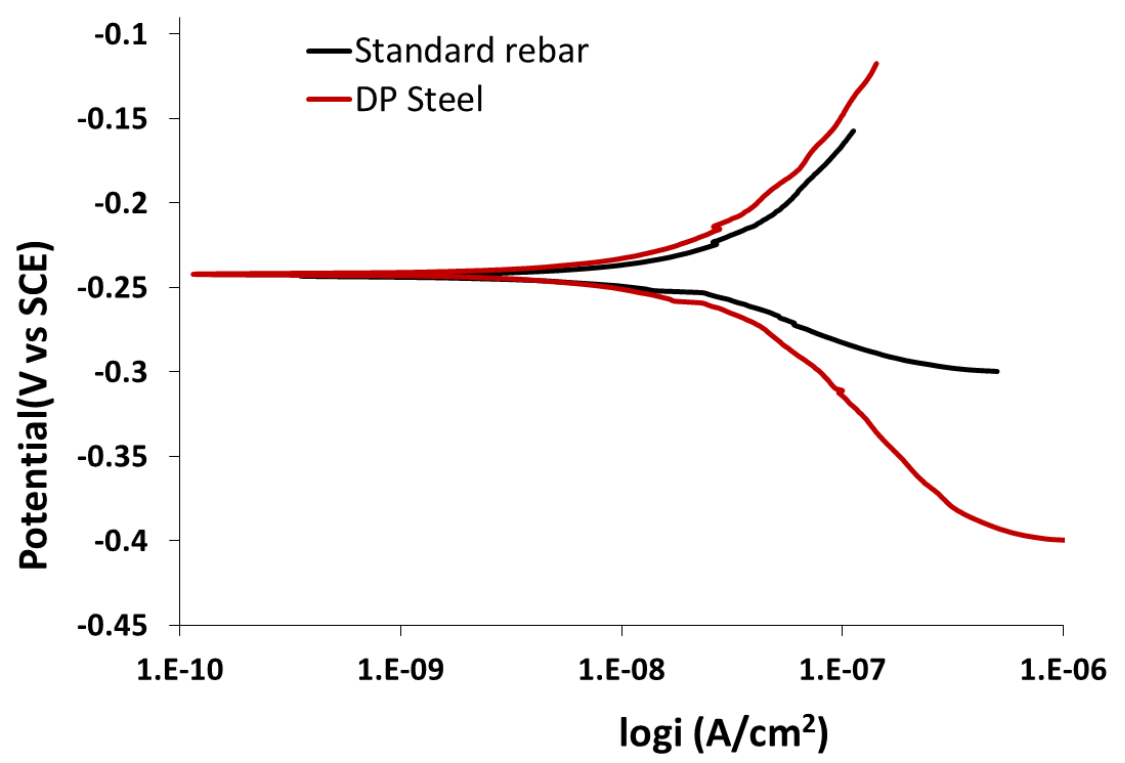

Figure 9. Potentiodynamic polarization results for standard rebar and DP steel in $0.3 \mathrm{M} \mathrm{NaHCO}_{3}+$ $0.1 \mathrm{M} \mathrm{Na}_{2} \mathrm{CO}_{3}(\mathrm{pH}=9.0)$ solution. 


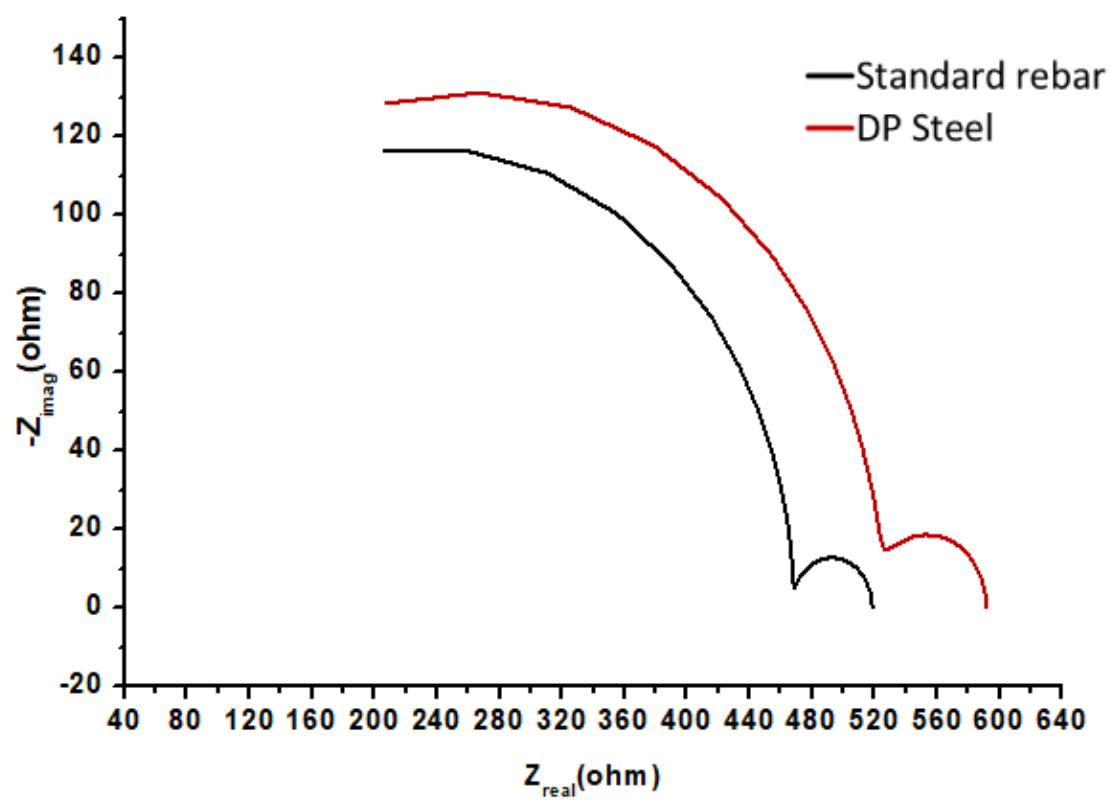

Figure 10. EIS results (Nyquist plots) for standard rebar and DP steel in $0.3 \mathrm{M} \mathrm{NaHCO}_{3}+0.1 \mathrm{M}$ $\mathrm{Na}_{2} \mathrm{CO}_{3}(\mathrm{pH}=9.0)$ solution.

From the SEM images, it is clear that rebar (Figure 11a) has a higher pitting corrosion density and that DP steel (Figure 11b) has an exfoliation-type corrosion in $0.3 \mathrm{M} \mathrm{NaHCO}_{3}+0.1 \mathrm{M} \mathrm{Na}_{2} \mathrm{CO}_{3}$ $(\mathrm{pH}=9.0)$ solution. The parameters obtained from Figures 9 and 10 are listed in Table 5. Here, $\mathrm{E}_{\mathrm{Corr}}$ is the corrosion potential and $\mathrm{j}_{\mathrm{Corr}}$ is the corrosion current density.
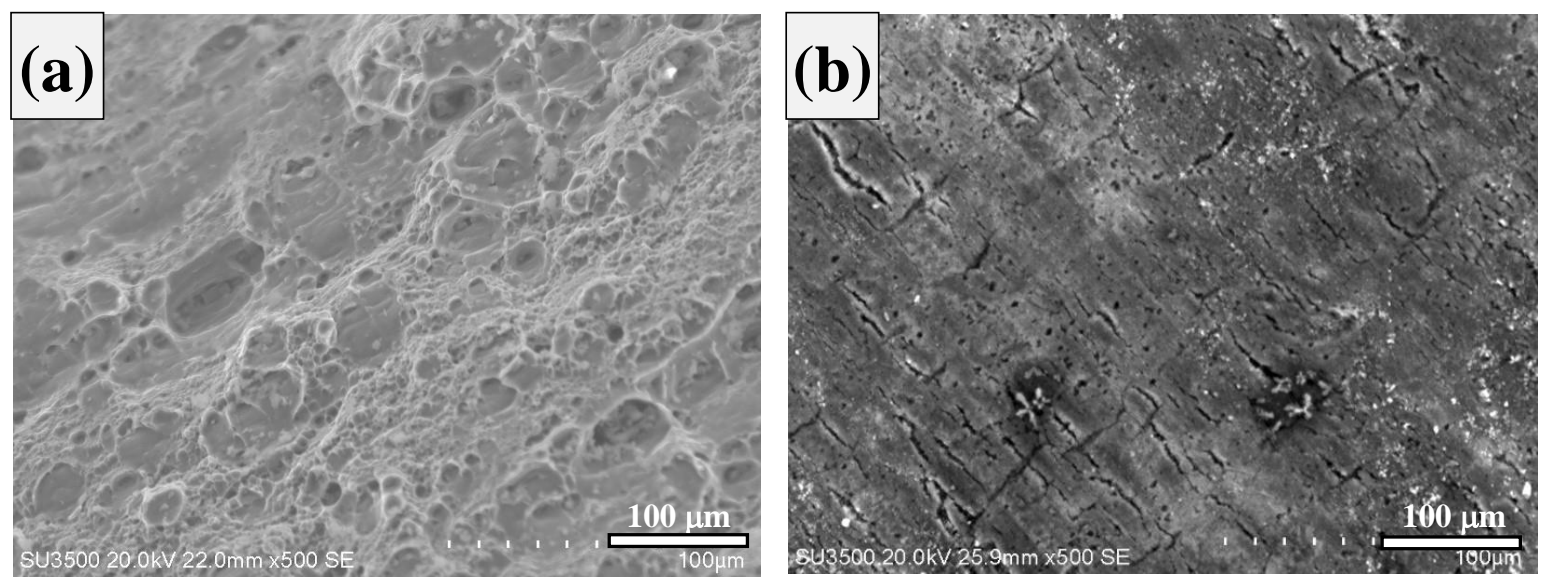

Figure 11. SEM images obtained after immersion in $0.3 \mathrm{M} \mathrm{NaHCO}_{3}+0.1 \mathrm{M} \mathrm{Na}_{2} \mathrm{CO}_{3}(\mathrm{pH}=9.0)$ solution. (a) Standard rebar and (b) DP steel.

Table 5. EIS results for DP steel and standard rebar in $0.3 \mathrm{M} \mathrm{NaHCO} 3+0.1 \mathrm{M} \mathrm{Na}_{2} \mathrm{CO}_{3}$ $(\mathrm{pH}=9.0)$ solution.

\begin{tabular}{ccccc}
\hline Sample & $\begin{array}{c}\text { Icorr } \\
\left(\mu \mathrm{A} / \mathbf{c m}^{\mathbf{2}}\right)\end{array}$ & $\begin{array}{c}\text { Ecorr } \\
\mathbf{( V )}\end{array}$ & $\begin{array}{c}\mathbf{R p} \\
\left(\mathbf{\Omega . c \mathbf { c m } ^ { 2 } )}\right.\end{array}$ & $\boldsymbol{\alpha}$ \\
\hline Standard rebar & 9 & -0.24 & 470 & -0.92 \\
DP steel & 5 & -0.24 & 600 & -0.98 \\
\hline
\end{tabular}




\subsection{4. $0.015 \mathrm{M} \mathrm{NaHCO}_{3}+0.005 \mathrm{M} \mathrm{Na}_{2} \mathrm{CO}_{3}(\mathrm{pH}=9.0)$ Solution}

Upon lowering the concentration of $\mathrm{NaHCO}_{3}$ (sodium bicarbonate) and $\mathrm{Na}_{2} \mathrm{CO}_{3}$ (sodium carbonate) in the solution, the anodic polarization curves change. Specifically, the corrosion potential decreases and the passivity disappears. An increasing corrosion potential also leads to an increase in the potential; therefore, the current density also rapidly increases to a certain limit where the transportation or movement of ions through the corrosion products on the surface is clearly observed. The behavior of rebar and DP steel in the above solution are shown in Figures 12 and 13. The corrosion rate of DP steel is lower than that of rebar in this solution.



Figure 12. Potentiodynamic polarization results for standard rebar and DP steel in $0.015 \mathrm{M} \mathrm{NaHCO}_{3}+$ $0.005 \mathrm{M} \mathrm{Na}_{2} \mathrm{CO}_{3}(\mathrm{pH}=9.0)$ solution.

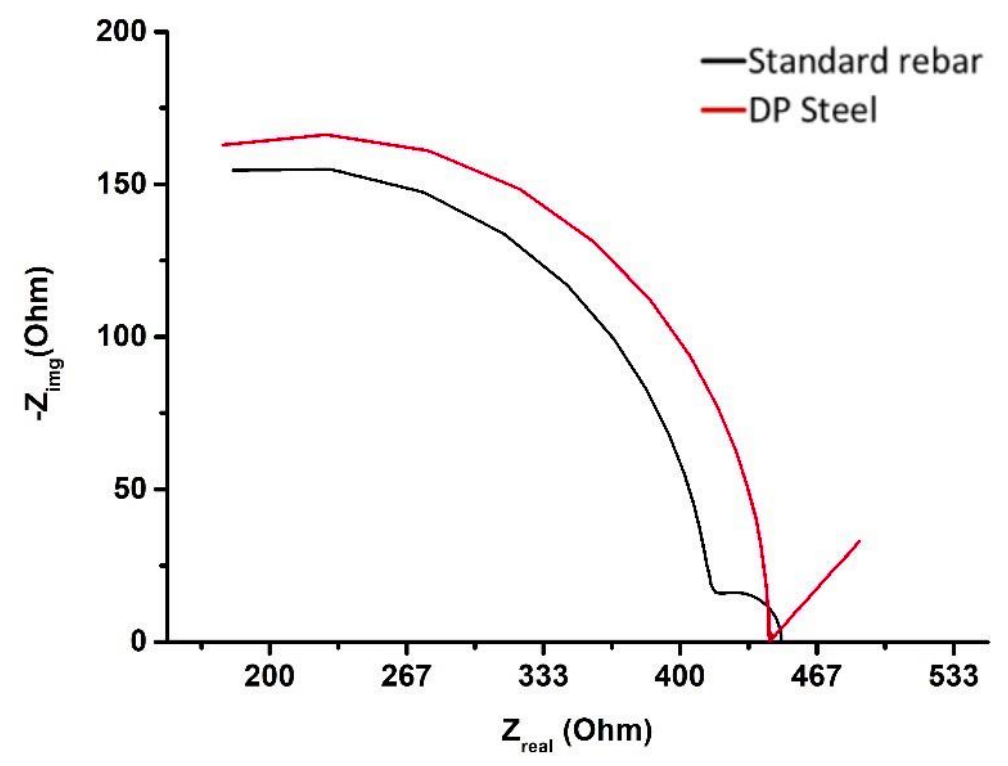

Figure 13. EIS results (Nyquist plots) for standard rebar and DP steel in $0.015 \mathrm{M} \mathrm{NaHCO}_{3}+0.005 \mathrm{M}$ $\mathrm{Na}_{2} \mathrm{CO}_{3}(\mathrm{pH}=9.0)$ solution.

As shown by the SEM images, rebar (Figure 14a) undergoes a more uniform corrosion than DP steel (Figure 14b) in $0.015 \mathrm{M} \mathrm{NaHCO}_{3}+0.005 \mathrm{M} \mathrm{Na}_{2} \mathrm{CO}_{3}(\mathrm{pH}=9.0)$ solution. The parameters obtained 
from Figures 12 and 13 are listed in Table 6. Here, $\mathrm{E}_{\mathrm{Corr}}$ is the corrosion potential and $\mathrm{j}_{\mathrm{Corr}}$ is the corrosion current density.
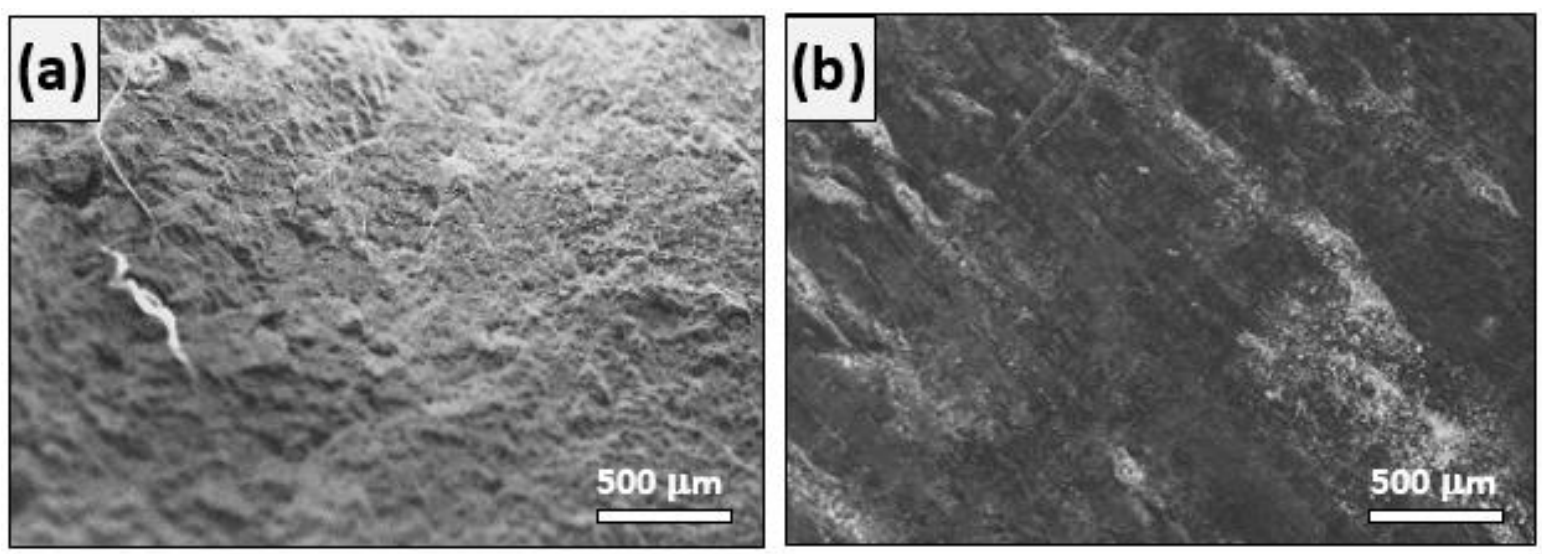

Figure 14. SEM images obtained after immersion in $0.015 \mathrm{M} \mathrm{NaHCO}_{3}+0.005 \mathrm{M} \mathrm{Na}_{2} \mathrm{CO}_{3}(\mathrm{pH}=9.0)$ solution. (a) Standard rebar and (b) DP steel.

Table 6. EIS results for DP steel and standard rebar in $0.015 \mathrm{M} \mathrm{NaHCO}_{3}+0.005 \mathrm{M} \mathrm{Na}_{2} \mathrm{CO}_{3}$ $(\mathrm{pH}=9.0)$ solution.

\begin{tabular}{ccccc}
\hline Sample & $\begin{array}{c}\text { Icorr } \\
\left(\boldsymbol{\mu} \mathbf{A} / \mathbf{c m}^{\mathbf{2}}\right)\end{array}$ & $\begin{array}{c}\text { Ecorr } \\
(\mathbf{V})\end{array}$ & $\begin{array}{c}\mathbf{R p} \\
\left(\mathbf{\Omega} \cdot \mathbf{c m}^{\mathbf{2}}\right)\end{array}$ & $\boldsymbol{\alpha}$ \\
\hline Standard rebar & 4 & -0.25 & 345 & -0.89 \\
DP steel & 1 & -0.18 & 456 & -0.92 \\
\hline
\end{tabular}

\section{Discussion}

Previous results show the tendency of rebar steel for passivity at the free corrosion potential in highly alkaline media. This is clearly confirmed from the corrosion potential values and the polarization measurements (Figure 3, Figure 6, Figure 9, and Figure 12) recorded in the calcium hydroxide and sodium hydroxide solutions. These outcomes are in accordance with the balance potential $\mathrm{pH}$ chart for the $\mathrm{FeH}_{2} \mathrm{O}$ framework. According to that chart, in alkaline media (like calcium hydroxide and sodium hydroxide), an inactive oxide layer will be generated and cover the surface to protect the base matrix from active corrosion by activating the passive state.

Calvert and Kruger [18] proposed Iron (II, III) oxide $\left(\mathrm{Fe}_{3} \mathrm{O}_{4}\right)$ and ferric oxide $\left(\mathrm{Fe}_{2} \mathrm{O}_{3}\right)$ as the main compounds forming the passive layer in alkaline solutions. Smialowska et al. found that there was no difference between the components forming the passive layers generated in $\mathrm{Ca}(\mathrm{OH})_{2} / \mathrm{NaOH}$ and $\mathrm{Fe}_{3} \mathrm{O}_{4} / \mathrm{Fe}_{2} \mathrm{O}_{3}$. Finally, Yonezawa et al. [25] concluded that in calcium hydroxide solution a broken calcium hydroxide film covered the metal surface.

In highly alkaline media, an increasing chloride content has a significant effect on Tata steel's corrosion behavior. A high chloride concentration decreases the potential to a limit where the process of passivity breakdown can begin. A potentiodynamic analysis helps to determine the optimum concentration of chloride ions that can initiate pitting on the metal surface. The optimum chloride concentration is defined as the maximum chloride percentage that can be added without initiating pitting corrosion on the metallic surface. The optimum chloride concentration has a proportional relationship with the $\mathrm{pH}$ of the solution.

Galvele [26] has developed a new pitting mechanism for the localized corrosion of carbon steel defined as critical acidification, where maintaining an acidic film with a certain concentration at the metal solution interface is important for initiating pitting. Critical acidification is a property of each alloy and metal. It is required for repassivation and pitting propagation. 
In order to study the corrosion behaviors of the steels, corrosion experiments were performed in simulated concrete pore solutions at constant carbonate and bicarbonate ratios and constant $\mathrm{pH}$ values. It was observed that the chloride ion concentration was the only parameter that affected the corrosion rate of the steel. The $\mathrm{E}_{\mathrm{corr}}$ values and instantaneous corrosion rates were measured in high-carbonate and -bicarbonate concentration solutions, assuming that there was a passive protection layer formed between the solution and the metal surface. Furthermore, the polarization and potentiodynamic analysis results showed that no attack was detected at the sample surface because of the relatively low current density.

In our case, standard rebar steel undergoes a generalized corrosion behavior upon immersion in a low-carbonate and -bicarbonate concentration solution $\left(0.005 \mathrm{M} \mathrm{Na}_{2} \mathrm{CO}_{3}+0.015 \mathrm{M} \mathrm{NaHCO}_{3}\right)$ during the anodic polarization process. This conclusion can be confirmed by the relatively low corrosion potential values and the high corrosion rate values obtained when the steel was exposed for a longer time to that diluted solution.

It was suggested by Davies and Thomas [27] that the proportional relationship between the $\mathrm{Fe}$ (III) passive layer stability on a steel surface and the carbonate/bicarbonate solution concentration resulted from the lower values of the Flade potential. Consequently, a higher carbonate/bicarbonate concentration will protect the passive layer from loosestrife and vice versa. From the anodic polarization curves, several authors [28-31] have confirmed the presence of two important current density peaks for carbon steel in carbonate/bicarbonate solutions. The first peak, at $\mathrm{E}<-0.2 \mathrm{~V}$, indicates the formation of a passive film via the transformation from metallic iron $(\mathrm{Fe})$ to ferrous ion $\left(\mathrm{Fe}^{2+}\right)$ :

$$
\begin{gathered}
\mathrm{Fe}+2 \mathrm{H}_{2} \mathrm{O} \rightarrow \mathrm{Fe}(\mathrm{OH})_{2}+2 \mathrm{H}_{2}+2 \mathrm{e}^{-} \\
\mathrm{Fe}+\mathrm{HCO}_{3}{ }^{-} \rightarrow \mathrm{FeCO}_{3}+\mathrm{H}^{+}+2 \mathrm{e}^{-}
\end{gathered}
$$

The second peak was observed at $0.1 \mathrm{~V}$ by increasing the potential until a passive layer was generated:

$$
3 \mathrm{Fe}(\mathrm{OH})_{2} \rightarrow \mathrm{Fe}_{3} \mathrm{O}_{4}+2 \mathrm{H}_{2} \mathrm{O}+2 \mathrm{H}^{+}+2 \mathrm{e}^{-}
$$

Mao et al. [32] attributed the relationship between the carbonate/bicarbonate concentration in the solution and the changing shape of the polarization curve to the stability differences of the ferrous carbonate passive layer. Meanwhile, when the bicarbonate concentration decreased, the chance of forming the ferrous carbonate passive layer on the metal surface increased.

Moreover, the stability of the solution could be altered by the dispersal of ferrous cations from the metal surface causing the degradation of the passive layer. In this case, a continuous competitive relationship will occur over time between the degradation and formation processes of the passive layer. Formation occurs in a low $\mathrm{HCO}_{3}$ concentration solution, while dissolution occurs if passivation does not occur at higher potentials. In all solutions, DP steel shows a low corrosion rate. The as-received sample has a pearlite and ferrite structure. DP has a ferrite-martensite structure.

\section{Conclusions}

A comparative study of the corrosion of DP steel and conventional standard rebar was performed. The following conclusions were drawn:

1. DP steel preserves its passive state in highly alkaline media and environments (i.e., high-carbonate/ bicarbonate concentrations), even in the high potential range. A generalized corrosion of DP steel occurs at any potential that is higher than the free corrosion potential in the case of low carbonate/bicarbonate concentrations because there is no chance of passivation.

2. From a mechanical point of view, the pitting process is mainly affected by the degree of alkalinity of the solution (i.e., carbonate/bicarbonate concentrations). In highly alkaline solutions, pitting is initiated by the laceration of the passive layer, while in low-concentration solutions, pitting initiates on surfaces that are subject to a generalized corrosion. 
3. The localized corrosion of DP steel can be improved by either increasing the solution $\mathrm{pH}$ or the alkalinity degree, which has a salutary effect on chloride effectiveness. Chloride plays an important role in increasing the corrosion rate by breaking the passive layer. Thus, in order to protect a structure from corrosion, the alkalinity of the solution should be increased (i.e., the $\mathrm{pH}$ should be high).

4. The value of $i_{\text {corr }}$ is higher for conventional rebar than for DP steel. The polarization value is inversely proportional to $i_{\text {corr }}$, and this theoretical aspect is confirmed by the EIS results. In all solutions, the polarization resistance is higher for DP steel than for conventional rebar.

5. Based on all of the analyses performed, it is concluded that DP steels exhibit a superior corrosion resistance and strength compared to conventional rebar. The reported results show that DP steels are good candidates for concrete reinforcement, especially in aggressive and corrosive environments.

Author Contributions: Conceptualization, H.S.A. and A.H.S.; Data curation, B.B.M., J.A.M., M.S.A. and S.A.R.; Formal analysis, A.H.S. and S.A.R.; Funding acquisition, A.H.S.; Investigation, H.S.A. and B.B.M.; Methodology, B.B.M., J.A.M., S.A.R. and H.S.A.; Resources, A.H.S.; Software, H.S.A.; Supervision, H.S.A.; Validation, J.A.M., S.A.R. and M.S.A.; Visualization, J.A.M., M.S.A. and S.A.R.; Writing-original draft, H.S.A. and A.H.S.; Writing-review \& editing, H.S.A. All authors have read and agreed to the published version of the manuscript.

Funding: This research was funded by Deanship of Scientific Research at King Saud University, grant number RG-1439-029.

Acknowledgments: The authors would like to extend their sincere appreciation to the Deanship of Scientific Research at King Saud University for its funding of this research through the Research Group Project No. RG-1439-029.

Conflicts of Interest: The authors declare no conflict of interest.

\section{References}

1. Alonso, C.; Andrade, C.; Castellote, M.; Castro, P. Chloride threshold values to depassivate reinforcing bars embedded in a standardized OPC mortar. Cem. Concr. Res. 2000, 30, 1047-1055. [CrossRef]

2. Alonso, C.; Castellote, M.; Andrade, C. Chloride threshold dependence of pitting potential of reinforcements. Electrochim. Acta 2002. [CrossRef]

3. Li, L.; Sagüés, A.A. Effect of chloride concentration on the pitting and repassivation potentials of reinforcing steel in alkaline solutions. In Proceedings of the NACE-International Corrosion Conference Series, San Antonio, TX, USA, 25-30 April 1999.

4. Bertolini, L.; Bolzoni, F.; Pastore, T.; Pedeferri, P. Behaviour of stainless steel in simulated concrete pore solution. Br. Corros. J. 1996, 31, 218-222. [CrossRef]

5. Hausmann, C.M. Corrosion of reinforcing bars in concrete. ACI J. Proc. 1965, 62. [CrossRef]

6. Gouda, V.K. Corrosion and corrosion inhibition of reinforcing steel: I. immersed in alkaline solutions. Br. Corros. J. 1970, 5, 198-203. [CrossRef]

7. Tasan, C.C.; Diehl, M.; Yan, D.; Bechtold, M.; Roters, F.; Schemmann, L.; Zheng, C.; Peranio, N.; Ponge, D.; Koyama, M.; et al. An overview of dual-phase steels: Advances in microstructure-oriented processing and micromechanically guided design. Annu. Rev. Mater. Res. 2015, 45, 391-431. [CrossRef]

8. Sezen, H.; Setzler, E.J. Reinforcement slip in reinforced concrete columns. ACI Struct. J. 2008. [CrossRef]

9. Dieter, G.E.; Bacon, D. Mechanical metallurgy. J. Frankl. Inst. 1962, 273, 338. [CrossRef]

10. Kuziak, R.; Kawalla, R.; Waengler, S. Advanced high strength steels for automotive industry. Arch. Civ. Mech. Eng. 2008, 8, 103-117. [CrossRef]

11. Zackay, V.; Parker, E.R.; Fahr, D.; Busch, R. The enhancement of ductility in high-strength steels. Trans. ASM $1967,60,252-259$.

12. Bode, R.; Meurer, M.; Schaumann, T.W.; Warnecke, W. Selection and use of coated advanced high-strength steels for automotive applications. Rev. Métallurgie 2004, 101, 551-558. [CrossRef]

13. Mintz, B. Hot dip galvanising of transformation induced plasticity and other intercritically annealed steels. Int. Mater. Rev. 2001, 46, 169-197. [CrossRef] 
14. Ball, A.; Chauhan, Y.; Schaffer, G.B. Microstructure, phase equilibria, and transformations in corrosion resistant dual phase steel designated 3CR12. Mater. Sci. Technol. 1987, 3, 189-196. [CrossRef]

15. Llewellyn, D.T.; Hillis, D.J. Dual phase steels. Ironmak. Steelmak. 1996, 23, 471-478.

16. Luqman, M.; Seikh, A.H.; Sarkar, A.; Ragab, S.A.; Mohammed, J.A.; Ijaz, M.F.; Abdo, H.S. A comparative study of the electrochemical behavior of $\alpha$ and $\beta$ phase Ti6Al4V alloy in Ringer's solution. Crystals 2020, 10, 190. [CrossRef]

17. Bleck, W.; Phiu-On, K. Microalloying of cold-formable multi phase steel grades. Mater. Sci. Forum 2005, 500-501, 97-114. [CrossRef]

18. Kruger, J.; Calvert, J.P. Ellipsometric-potentiostatic studies of iron passivity. J. Electrochem. Soc. 1967, $114,43$. [CrossRef]

19. Verdeja, J.I.; Pero-Sanz, J.A.; Asensio, J. Multiphase steels: Structure-mechanical properties relationships in the cold rolled and continuous annealed condition. Mater. Sci. Forum 2005, 500-501, 429-436. [CrossRef]

20. Katiyar, P.K.; Behera, P.K.; Misra, S.; Mondal, K. Comparative corrosion behavior of five different microstructures of rebar steels in simulated concrete pore solution with and without chloride addition. J. Mater. Eng. Perform. 2019, 28, 6275-6286. [CrossRef]

21. Ismail, M.; Muhammad, B.; Hamzah, E.; Keong, T. Corrosion behaviour of dual-phase and galvanized steels in concrete. Anti-Corros. Methods Mater. 2012, 59, 132-138. [CrossRef]

22. Trejo, D.; Monteiro, P.; Thomas, G.; Wang, X. Mechanical properties and corrosion susceptibility of dual-phase steel in concrete. Cem. Concr. Res. 1994, 24, 1245-1254. [CrossRef]

23. Ismail, M.; Hamzah, E.; Guan, G.C.; Rahman, I.A. Corrosion performance of dual-phase steel embedded in concrete. Arab. J. Sci. Eng. 2010, 35, 81-90.

24. Salamci, E.; Candan, S.; Kabakci, F. Effect of microstructure on corrosion behavior of dual-phase steels. Kov. Mater. 2017, 55, 133-139. [CrossRef]

25. Yonezawa, T.; Ashworth, V.; Procter, R.P.M. Pore solution composition and chloride effects on the corrosion of steel in concrete. Corrosion 1988, 44, 489-499. [CrossRef]

26. Galvele, J.R. Transport processes and the mechanism of pitting of metals. J. Electrochem. Soc. 1976, $123,464$. [CrossRef]

27. Thomas, J.G.N.; Davies, J.D. Influence of hydrogen carbonate and chloride ions on the stability of oxide films on mild steel in near-neutral solutions. Br. Corros. J. 1977, 12, 108-114. [CrossRef]

28. Parsons, R. Atlas of electrochemical equilibria in aqueous solutions. J. Electroanal. Chem. Interfacial Electrochem. 1967, 13, 471. [CrossRef]

29. Galvele, J.R. Effect of molybdenum on the pitting potential of high purity $18 \% \mathrm{Cr}$ ferritic stainless steels. J. Electrochem. Soc. 1978, 125, 1204. [CrossRef]

30. Bellezze, T.; Giuliani, G.; Roventi, G. Study of stainless steels corrosion in a strong acid mixture. Part 1: Cyclic potentiodynamic polarization curves examined by means of an analytical method. Corros. Sci. 2018, 130, 113-125. [CrossRef]

31. Abdo, H.S.; Sherif, E.-S.M.; El-Serehy, H.A. Manufacturing of Ti-6\%Al and Ti-6\%Al-4\%V alloys and their corrosion in sodium chloride solutions. Crystals 2020, 10, 181. [CrossRef]

32. Mao, X.; Liu, X.; Revie, R.W. Pitting corrosion of pipeline steel in dilute bicarbonate solution with chloride ions. Corrosion 1994, 50, 651-657. [CrossRef]

Publisher's Note: MDPI stays neutral with regard to jurisdictional claims in published maps and institutional affiliations.

(C) 2020 by the authors. Licensee MDPI, Basel, Switzerland. This article is an open access article distributed under the terms and conditions of the Creative Commons Attribution (CC BY) license (http://creativecommons.org/licenses/by/4.0/). 